\title{
KOMUNIKASI BUDAYA DALAM MENINGKATKAN PARTISIPASI PEMILIH DI KOTA PARIAMAN
}

\author{
Widya Hasan ${ }^{1 *}$,Asmawi ${ }^{2}$, Najmuddin Rasul ${ }^{3}$
}

\begin{abstract}
Downward trend voter participation in the election of the Governor and Deputy Governor of West Sumatra Province in Kota Pariaman needs special attention, because percentage of voters who use votes at polling stations is still a benchmark for the amount of public trust in the elected regional heads through the election mechanism. Therefore is needed communication pattern that can provide understanding and educating the public about the importance of exercising voting rights during elections. Like a pattern of socialization that puts forward a cultural approach (Local Wisdom) that can inspire people to use their voting rights at TPS. This research method is descriptive qualitative that aims to understand and interpretation the meaning of events, interactions and human behavior through communication with cultural approaches. That form of 'Ciloteh Lapau' which is one of the media for election socialization and education to increase voter participation in Kota Pariaman.
\end{abstract}

Keywords: Culture Communication, Governor Election, Voter Participation, Pariaman

\section{A. PENDAHULUAN}

$\mathrm{P}$ emilu merupakan perhelatan lima tahunan yang diselenggarakan untuk memilih pemimpin apakah itu kepala daerah, Anggota DPR, DPRD, DPD dan Presiden dan Wakil Presiden. Pemilu merupakan salah satu bentuk pelaksanaan kedaulatan rakyat, karena dengan pemilu rakyat dapat memilih pemimpin secara langsung dengan cara menggunakan hak pilihnya di TPS.

Dalam menyelenggarakan pemilu, perlu dilakukan pendidikan pemilih untuk menanamkan kesadaran kepada masyarakat akan pentingnya menggunakan hak pilih pada pemilu diperlukan suatu upaya yang nyata dan langsung menyentuh masyarakat itu sendiri dalam pelaksanaannya. Salah satu upaya yang ditempuh melalui pendidikan pemilih adalah dengan melaku-

\footnotetext{
${ }^{1}$ Graduate Student of Communication Science, FISIP, Universitas Andalas, Padang.

${ }^{2}$ Department of Communication Science, FISIP, Universitas Andalas, Padang.

${ }^{3}$ Faculty of Law, Universitas Andalas, Padang.

*Corresponding Author: widyahasan38@gmail.com
}

kan kegiatan sosialsasi kepada masyarakat tujuannya agar untuk mengedukasi dan mengiformasikan bahwa dengan berpartisipasi dalam pemilu merupakan suatu wujud perlaksnaaan tanggungjawab sebagai Warga Negara. Pemilu merupakan mekanisme pergantian pemimpin secara sistematis.

Dimasyarakat Minang Kabau, khususnya di Pariaman sosialisasi pemilu perlu dilakukakan dengan menggunakan pendekatan budaya, karena kebiasaan dan pola sosial masyarakat juga sangat berpengaruh terhadap suksesi dari kelancaran pemilu di suatu daerah.Tidak dapat dipungkiri, tinggi atau rendahnya partisipasi masyarakat dalam pemilu memiliki korelasi terhadap pemahaman masyarakat akan pentingnya mensukseskan pemilu di masing-masing daerah.

Sebagai penyelenggara pemilu, Komisi Pemilihan Umum merupakan lembaga negara yang yang bertugas untuk menyelenggarakan pemilihan umum di Indonesia, adapun pemilu meliputi Pemilihan Anggota DPR/ DPD/ DPRD, serta

DOI: 10.25077/jantro.v20.n2.p179-189.2018

JANTRO ISSN: 2355-5963 (Online)

under Lisensi Creative Commons Atribusi-BerbagiSerupa 4.0 Internasional 
Pemilihan Umum Presiden dan Wakil Presiden, dan Pemilihan umum Kepala Daerah dan Wakil Kepala Daerah. Komisi Pemilihan Umum tidak dapat disejajarkan kedudukannya dengan lembaga-lembaga negara yang lain yang kewenangannya ditentukan dan diberikan oleh UUD 1945 (Asshiddiqie,2006:236).

Dalam menyelenggarakan pemilu, KPU memiliki tugas dan kewajiban untuk melayani masyarakat dalam menggunakan hak pilinnya. Untuk itu dibutuhkan suatu pola komunikasi yang dirancang untuk dapat bersentuhan langsung dengan masyarakat. Artinya sebagai lembaga Negara, KPU berupaya membangun komunikasi Agar setiap pogram kerja yang dilaksanakan dapat berjalan dengan baik dan mendapat dukungan dari masyarakat.

Sebagaimana kita pahami bersama bahwa komunikasi merupakan cara interaksi manusia dengan sesamanya. Komunikasi merupakan suatu proses pernyataan antar manusia untuk menyatakan pikiran, perasaan seseorang kepada orang lain dengan menggunakan bahasa sebagai alat penyalurnya (Effendy. 1993:28). Sedangkan kaitan antara komunikasi dan budaya dilihat pada cara hidup manusia disuatu tempat, meliputi, bahasa, kebiasaan, dan pola pikir juga dipengaruhi oleh kebiasaan yang melekat di suatu daerah. Jadi pada dasarnya budaya merupakan landasan komunikasi, bila budaya beraneka ragam, maka beraneka ragam pula praktik komunikasi (Mulyana, 2010:38)

Untuk itu perlu disusun suatu format kegiatan yang bersifat informatif dengan tujuan agar menggugah kesadaran mayarakat (persuasif) agar menggunakan hak pilinnya di TPS sebagai suatu perwujudan pelaksanaan kewajiban warga Negara untuk menggunakan hak pilihnya dalam rangka berpartisipasi untuk memilih pemimpin yang akan mengepalai pemerintahan untuk lima tahun kedepan.

Adanya hubungan timbal balik (reciprocal) antara komunikasi dan budaya. Yang akan berpengaruh terhadap persepsi yang akan memungkinkan pemberian makna (Pemaknaan) yang cenderung mirip (sama) pula terhadap suatu realitas sosial atau peristiwa. Sehingga dengan sendirinya akan mempengaruhi cara dan praktek berkomunikasi (Porter \& Larry, 1998:25).

Sebagaimana diungkapkan oleh Samovar dan Porter ada beberapa hal yang mempengaruhi komunikasi dan budaya yaitu;

a. Nilai (Value)

Nilai kebudayaan adalah sebagai aspek evaluatif dari sistem-sistem kepercayaan yang ada di masyarakat.

b. Sikap (Attitude)

Kepercayaan dan nilai berkontribusi pada pengembangan sikap. Realitas dan konteks budaya akan membentuk perilaku.

c. Pandangan (World View)

Adanya pandangan yang sama terhap konsepsi budaya yang ada dan berkembang dalam masyarakat seperti kesamamaan makna akan nilai, sikap, budaya, sehingga adanya kesamaan persepsi terhadap suatu pandangan terhadap budaya yang sama (Mulyana \& Rakhmat.1982:25-29).

Berkaca dari beberapa kegiatan sosialisasi yang telah dilaksanakan oleh KPU Kota Pariaman, adanya kecendrungan pelaksanaan sosialisasi sering dirumuskan dalam pola linear (satu arah) dengan bentuk propaganda saja. Pola linear tidak memberikan kesempatan bagi masyarakat untuk menanggapi atau sekedar mengkroscek informasi pemilu yang diperoleh. Sehingga ambiguitas atau ketidak pahaman akan proses pelaksanaan pemilu dapat diminimalisir dengan ketersediaan informasi yang mampu mengurangi ketidak pahaman masyarakat akan pentingnya menggunakan hak pilih dalam pemilu sehingga berujung pada rendahnya partisipasi masyarakat dalam pemilu. Maka dari itu perlu dirancang dan rumuskan suatu konsep pesan yang bersifat edutainment, yaitu pola komunikasi disusun untuk lebih menekankan pada aspek edukasi dan tidak lupa menyematkan konsep hiburan agar komunikasi yang

$180 \mid \mathrm{P}$ a g e

DOI: 10.25077/jantro.v20.n2.p179-189.2018

JANTRO ISSN: 2355-5963 (Online)

under Lisensi Creative Commons Atribusi-BerbagiSerupa 4.0 Internasional 
dibangun menjadi menarik dan menyenangkan. Sehingga perlu dirancang satu pola komunikasi melalui kegiatan sosialisasi yang dilakukan dengan merancang suatu konsep kegiatan (packaging) pesan yang dibuat dengan menarik. Selain itu pemilihan saluran (media) juga mempengaruhi sejauh mana informasi yang disampaikan mampu mempengaruhi minat masyarakat yang tadinya apatis dengan pelaksanaan pemilu yang akan menghasilkan pemimpin yang mampu menghasilkan kebijakan yang akan membawa perubahan bagi masyarakat secara keseluruhan. Untuk itu perlu dilakukan upaya persuasif dan edukatif kepada masyarakat agar timbul kesadaran dan kesukarelaan untuk menggunakan hak pilihnya, karena partisipasi masyarakat berkaitan erat dengan keberhasilan pemilu.

Sebagaimana diungkapkan oleh Alo liliweri dalam dasar-dasar komunikasi Adapun tujuan komunikasi antar budaya meliputi:

1. Meningkatkan pengetahuan akan budaya yang berbeda dengan budaya kita;

2. Untuk meningkatkan pengetahuan dan pemahaman agar dapat berkomunikasi dengan baik (Komunikatif).

3. Mampu menjelaaskan kendala dan permasalahan antar budaya.

Melalui pendekatan budaya dan komunikasi yang baik, diharapkan pelaksanaan Pemilihan Umum dapat berjalan dengan tertib, aman dan lancar. Hal ini dikarenakan Pemilu merupakan perwujudan partisipasi pollitik masyarakat menurut Verba dan Nie bahwa Partisipasi Politik sebagai cornerstone dan jantung demokrasi. Sementara itu, dilain sisi, Halender mengungkapkan bahwa patisipasi politik merupakan prasyarat utama dalam sebuah Negara demokrasi, serta dipertegas oleh Sylvester dan McGlynn yang menyatakan bahwa demokrasi tidak akan bermakna apa-apa dan legitimasi tanpa ada partisipasi warga dalam proses demokrasi. Dengan kata lain, tingginya partisipasi masyarakat dalam pemilu merupakan perwujudan legitimasi dan kepercayaan masyarakat terhadap kepala daerah yang terpilih sebagai pemenang dalam pilkada (Najmuddin.2015:193).

Budaya merupakan suatu sistem ide, nilai, kepercayaan, struktur dan praktik yang dikomunikasikan suatu generasi ke generasi berikutnya untuk menopang cara hidup tertentu. Budaya muncul ketika cara hidup yang berbeda membentuk apa yang dipercaya, dihargai dan dilakukan oleh sekelompok orang.

Pola komunikasi yang dilakukan oleh KPU Kota Pariaman dalam meningkatkan partisipasi masyarakat dalam pemilu sangat bergantung pada upaya yang dilakukan oleh KPU Kota Pariaman dalam mengedukasi masyarakat untuk menjalankan hak konstitusinya sebagai warga Negara dengan terlibat aktif dalam pelaksanaan pemiliihan Umum dan dengan kesadaran yang tinggi menggunakan hak pilihnya sesuai dengan TPS terdaftar sebagai pemilih yang disesuaikan dengan tempat tinggal (domisili).

Terkait dengan perolehan suara dan partisipasi masyarakat dalam pemilu disajikan dalam tabel berikut ini tentang perolehan suara pada Pemilihan Gubernur dan Wakil Gubernur Provinsi Sumatera Barat di Kota Pariaman.

\section{Tabel 1.}

Perbandingan Partisipasi Pemilih di Kota Pariaman dari Tahun 2010 dan 2015

\begin{tabular}{ccc}
\hline Pilgub & $\begin{array}{c}\text { Jumlah Pengguna } \\
\text { Hak Pilih }\end{array}$ & $\begin{array}{c}\text { Persentase } \\
(\%)\end{array}$ \\
\hline 2010 & 30.394 & $52.66 \%$ \\
2015 & 31.630 & $53.16 \%$ \\
\hline
\end{tabular}

Sumber: KPU Provinsi Sumbar

Dari data diatas dilihat adanya peningkatan partisipasi pemilih dikarenakan adanya perobahan pola komunikasi yang dilakukan sehingga terjadi peningkatan partisipasi pemilih sebesar $1,50 \%$ jika dibandingkan dengan tahun 2010. Pentingnya pelaksanaan sosialisasi dalam pemilu berperan sebagai upaya untuk melakukan edukasi dan mempersuasi masyarakat agar 
menyadari manfaat menggunakan hak konstitusinya dalam pemilu. Karena setiap daerah memiliki budaya dan kearifan lokal yang menjadi pemersatu bagi masyarakat.

Untuk meningkatkan kesadaran masyarakat akan pentingnya pemilu, maka diperlukan suatu konsep komunikasi dengan mengedapankan budaya masyarakat (kearifan lokal) sehingga pemilu yang dilaksanakan dapat menjangkau masyarakat secara keseluruhan dan mengakomodir aspek sosial dan budaya yang telah lekat dengan keseharian masyarakat.

Adapun upaya yang dilakukan untuk menjangkau masyarakat secara keseluruhan untuk menimbulkan motivasi dan meningkatkan kesadaran untuk menggunakan hak politiknya adalah dengan melakukan sosialisasi dengan mengedepankan pendekatan budaya.

Untuk mengukur efek komunikasi yang dilakukan melalui kegitan sosialisasi 'Ciloteh Lapau' maka perlu dilihat kembali, apabila audience yang dituju sangat beragam, karena dalam kegiatan ini seluruh masyarakat yang ada di lapau saat itu dapat berperan dalam kegiatan yang diselenggarakan KPU Kota Pariaman. Seperti ditekenkan diatas kegiatan Ciloteh Lapau dilaksanakan melalui metode diskusi yang dihadiri kalangan masyarakat dengan tingkat pendidikan dan ekonomi yang beragam pula, maka perlu diukur seberapa efektif suatu kegiatan sosilisasi mampu memberikan pemahaman, mendidik masyarakat tentang kesadaran akan hak politiknya.

Melalui Teori Komunikasi Massa sebagaimana diungkapkan Marvin D'Flour untuk mengukur pengaruh (effect) komunikasi terhadap kehidupan masyarakat terhadap terpaan informasi yang serempak (Rivers,William.2004:32).

Khusus untuk masyarakat Kota Pariaman yang terkenal dengan kebiasaan nongkrong dilapau untuk sekedar berbincang (maotaota) dan membahas berbagai macam hal yang tengah terjadi di kehidupan masyarakat saat itu. Sehingga lapau menjadi sebuah institusi penting dalam pergaulan masyarakat.
Sebagaimana ungkapan yang menyatakan bahwa 'Silat kata berbeda dengan silat lidah, dalam makna yang lebih spesifik. Silat katanya memiliki makna positif. Dipakai oleh Niniak Mamak (pimpinan kaum atau suku) dalam dialog adat atau retorika di hadapan kaumnya, dan bertutur ke kemenakan.' (Yose Hendra, 2017)

Sedangkan Silat lidah di lepau mengunyah beragam isu dan persoalan, lalu dimuntahkan dalam riak-riak kata seperti debat kusir. Untuk masyarakat Kota Pariaman Lapau merupakan institusi penting dalam membangun suatu konstalasi sosial, politik yang yang langsung bersinggungan dengan masyarakat secara luas. Atau sering dikenal dengan akar rumput, karena keberadaanya yang begitu lekat dengan masyarkat.

Dilapau masyarakat dapat mengekspresikan apa yang mereka rasakan melalui dialogh secara demokratis karena ruang debat di lapau bisa dikatakan perwujudan bertutur tidak teratur yang dibungkus metafora candaan yang bersifat cemeeh, mendukung atau menjatuhkan lawan bicara adalah hal biasa yang kita temui.

Mencermati hal itu KPU Kota Pariaman selaku Penyelenggara Pemilu melihat bahwa salah satu upaya yang bisa ditempuh untuk memberikan pendidikan kepemiluan kapada masyarakat dapat dilakukan melalui upaya pendekatan budaya dengan membangun komunikasi yang afektif melalui mekanisme diskusi yang yang berkaitan erat dengan pelaksanaan pemilu yang dapat dilakukan dilapau dengan metode "Ciloteh Lapau" adalah suatu upaya untuk menampung semua aspirasi dan unek-unek masyarakat terkait dengan penyelenggaraan pemilu yang sedang dilaksanakan. Dengan melaksanakan diskusi langsung dengan masyarakat bertujuan untuk memberikan pengaruh yang besar terhadap kesadaran masyarakat dalam mengguankan hak pilinnya di TPS pada saat pemungutan suara dilaksanakan.

Sebagaimana kita pahami bersama, pentingnya memilih saat pemilu adalah untuk mendapatkan pemimpin yang akan 182 | P a g e

DOI: 10.25077/jantro.v20.n2.p179-189.2018 
diberi amanah untuk memimpin masyarakat untuk lima tahun mendatang. Kemajuan dan kemunduran daerah juga bergantung pada kebijkan yang dihasilkan selama kepemimpinannya. Untuk itu masyarakat sebagai pemegang hak pilih harus memahami betapa berperannya satu suara yang dimilikinya untuk menentukan siapa yang akan menjadi pemimpin diamasa yang akan datang.

Melalui sosialisasi dan diskusi secara langsung dengan masyarakat ini diharapkan mampu menampung aspirasi dan menumbuhkan kesadaran akan pentingnya menggunakan hak pilih dalam pemilu.

\section{B. METODE PENELITIAN}

$\mathrm{P}$ enelitian ini telah dilaksakan di Kota Pariaman. Alasan pemilihan Lokasi Penelitian ini dikarenakan pada tahun 2015 Kota Pariaman mengalami peningkatan jumlah partisipasi pemilih sebesar $1.50 \%$ jika dibandingkan dengan Pemilihan Gubernur yang diadakan pada tahun 2010.

Peningkatan partisipasi pemilih ini berkatan erat dengan pola komunikasi yang dibangun oleh KPU Kota Pariaman selaku penyelenggara pemilu dengan masyarakat. Dimana biasanya sosialisasi pemilu dilakukan lebih menekankan pada aspek formal saja, namun pada Pilgub tahun 2015 dirobah dengan melakukan pendekatan budaya yang ada, sehingga informasi yang berkaitan dengan pemilu dapat diketahui masyarakat secara luas. Tidak hanya bersifat ekslusif pada beberapa orang saja.

Sebagaimana yang diungkapkan Joseph De Vito ada dua tujuan pembicaraan persuasif yaitu Pembicaraan untuk memperkuat atau mengubah sikap atau kepercayaan Banyak pembicaraan yang ditujukan untuk memperkuat pembicaraan sikap atau kepercayaan yang sudah ada. Sementara itu, pembicaraan yang dirancang untuk. Mengubah sikap dan kepercayaan lebih sulit (Devito.1997:447). Kebanyakan orang menolak perubahan. Oleh karena itu perlu mempertimbangkan prinsip-prinsip berikut:

1. Perkirakanlah dengan cermat tingkat sikap dan kepercayaan komunikan.
2. Upayakan perubahan sedikit demi sedikit.

3. Berikan alasan yang meyakinkan untuk membuat komunikan mempercayai apa yang Anda inginkan.

Desain penelitian ini bersifat kualitatif bertujuan untuk memahami objek secara mendalam. Sedangkan metode penelitian bersifat deskriptif dimana penellitian ini tidak bertujuan untuk mencari dan menjelaskan hubungan atau menguji hipotesis. Penelitian kualittatif adalah penelitian yang bertujuan untuk memahami dan menafsirkan makna suatu peristiwa, interaksi dan tingkahlaku manusia dalam situasi tertentu (Sugiyono, 2016).

Seperti yang diungkapkan Sugiyono bahwa penelitian kualitatif merupakan penelitian yang berlandaskan pada model postpositivisme. Yaitu suatu penelitian yang digunakan untuk meneliti kondisi objek yang bersifat alamiah (Sugiyono, 2016).

Adapun unit analisis dalam penelitian ini merupakan suatu yang berkaitan dengan fokus/ komponen yang diteliti dalam rangka mendapatkan data-data yang akurat (Moleong, 2005).

Menurut Suprayogo, unit analisis dalam penelitian dapat meliputi individu, kelompok dan organsiasi, benda dan waktu sesuai dengan fokus permasalahannya (Moleong, 2005).

Adapun unit analisis dalam penelitian ini adalah lembaga (KPU Kota Pariaman) sebagai penyelenggara pemilu di tingkat Kota Pariaman. Bagaimana membangun komunikasi dengan pendekatan budaya untuk mensosialisasikan pemilu yang untuk meningkatkan partisipasi dan kesadaran masyarakat dalam menggunakan hak pilih pada pemilihan Gubernur dan Wakil Gubernur Provinsi Sumatera Barat di tingkat Kota pariaman.

Adapun metode pengumpulan data dilakukan dengan teknik purposive sampling, yaitu peneliti menentukan sendiri sampel yang diambil didasarkan atas pertimbangan tertentu. Adapun yang menjadi sampel dalam penelitian ini adalah:

DOI: 10.25077/jantro.v20.n2.p179-189.2018

JANTRO ISSN: 2355-5963 (Online)

under Lisensi Creative Commons Atribusi-BerbagiSerupa 4.0 Internasional 
Tabel 1. Daftar Informan Yang Berhasil Diwawancarai

\begin{tabular}{|c|c|c|}
\hline No & Nama & Jabatan \\
\hline 1 & Boedi Satria, SE & $\begin{array}{c}\text { Ketua KPU } \\
\text { Kota Pariaman }\end{array}$ \\
\hline 2 & $\begin{array}{l}\text { Hendri Jalal, } \\
\text { S.Pd,MM }\end{array}$ & Sekretaris \\
\hline 3 & Akhirulsyah, SH & $\begin{array}{c}\text { Kasubbag } \\
\text { Teknis dan } \\
\text { Hupmas }\end{array}$ \\
\hline 4 & $\begin{array}{c}\text { Sulas Sri Netti, } \\
\text { SH }\end{array}$ & $\begin{array}{l}\text { Staf Teknnis } \\
\text { dan Hupmas }\end{array}$ \\
\hline 5 & $\begin{array}{c}\text { Masyarakat Kota } \\
\text { Pariaman }\end{array}$ & $\begin{array}{c}\text { Yang telah } \\
\text { mengikuti } \\
\text { Pemilu }\end{array}$ \\
\hline
\end{tabular}

Sumber: Data Primer, 2018.

Pemilihan sampel berkaitan erat dengan peran masing-masing dalam pelaksanaan pemilu di Kota Pariaman. Yang dilihat dari tugas dan fungsinya yaitu;

1. Ketua KPU Kota Pariaman bertugas sebagai penanggungjawab pelaksanaan pemilu secara melembaga

2. Sekretaris KPU Kota Pariaman bertugas untuk memfasilitasi, membantu pelaksanaan setiap kegiatan yang berkaitan dengan pemilu dengan mempersiapkan SDM, anggaran dan Tim Kerja yang bertugas untuk menjalankan semua aktvitas yang berkaitan dengan suksesnya pelaknsaan pemilu.

3. Kasubbag Teknis \& Hupmas adalah kepala bagian yang meiliki tuugas dan wewenang untuk melaksanakan kegiatan sosialisasi dan pendidikan pemilih kepada masyarakat secara keselutuhan.

4. Staf subbagian Teknis \& Hupmas adalah SDM yang bertugas untuk melaksaakan setiap kegiatan yang dibutuhkan dalam melaksanakan pendidikan pemilih.

5. Masyarakat adalah sasaran yang dituju untuk menumbuhkan kesadaran akan pentinggnya pemilu untuk kelanngsungan kehidupan bersama.
Untuk memberi penjelasan yang rinci terhadap permasalahan yang diteliti. Maka dilakukan pengumpulan data dengan cara wawancara mendalam (depth interview). Dengan informan. Selain itu juga dilakukan metode observasi terhadap relaitas sosial yang berkaitan erat dengan tingkat pengetahuan, perilaku dan potensi budaya yang ada di masyarakat juga menjadi bahan masukan untuk melihat sejauhmana komunikasi budaya berpengaruh terhadap peningkatan partisipasi pemilih di masyarakat.

Selain pengumpulan data primer, dilakukan juga pengumpulan data sekunder yang diperoleh dan diolah dari dokumen kepemiluan, literature dan studi kepustakaan yang berkaitan dengan penelitian.

Sedangkan teknis analisis data dalam penelitian kualitatif dilakukan dengan pelacakan dan pengaturan transkrip wawancara, catatan lapangan dan bahanbahan yang dikumpulkan agar dapat diinterprestasikan sebagai suatu temuan penelitian (Sugiyono, 2016).

Analisis data merupakan pengorganisasian data yang sudah dikumpulkan dan diatur sebagai satuan yang dapat dikelola untuk menentukan apa yang penting dan diputuskan sebagai hasil yang menjadi temuan dalam penelitian.

Analisis data yang digunakan dalam penelitian ini Menggunakan metode Miles \& Hubberman yang terdiri atas tiga unsur yaitu;

1. Reduksi data

2. Penyajian data

3. Penarikan kesimpulan

Tiga siklus analisis data yang dikemukakan oleh Miles \& Hubberman dalam penelitian kualitatif bertujuan untuk mencari hubungan dan menemukan pola dengan cara memilih dan memilah data hasil wawancara dari informan selanjutnya dilakukan pemisahan informasi yang terkait dengan pola komunikasi yang dilakukan oleh KPU Kota Pariaman dalam mensosialsiasikan pemilu dengan mengedepankan komunikasi budaya untuk menarik animo masyarakat untuk menggunakan hak pilinnya pada pemilihan 
Gubernur dan Wakil Gubernur Provinsi Sumater Barat tahun 2015 di Kota Pariaman.

Berdasarkan hasil wawancara yang dilakukan dengan responden, maka didapat beberapa pola komunikasi yang dibutuhkan untuk pelaksanaan sosialisasi pemilu dengan pola komunikasi langsung. Pendekatan budaya dilakukan sebagai upaya agar masyarakat dapat menerima informasi yang berkaitan dengan pemilu melalui komunikasi tatap muka. Konsep komunikasi ini dilakukan dengan menyesuaikan pada latar sosial budaya masyarakat di pariaman yaitu 'ngobrol' di lapau.

Komunikasi langsung dengan berlatar lapau sebagai tempat pelaksanaan sosialisasi pemilu, dengan setting komunikasi berlatar sosial yang biasa dilakukan masyarakat ini diharapkan dapat mempermudah masyarakat untuk memahami bagaimana pentingnya pemilu untuk kelangsungan kehidupan bersama, karena pemilu tujuannya untuk menghasilkan pemimpin yang akan membuat berbagai macam keputusan yang akan berpengaruh terhadap kemaslahatan masyarakat banyak.

Selanjutnya data yang telah diperoleh dikelompokan sesuai dengan kegiatan sosialiasi pemilu yang dilakukan berdasarkan konsep sosialisasi pemilu dengan mengedepankan pendekatan budaya yaitu diskusi langsung dengan masyarakat (two way symmetric Communication) dengan melihat adanya umpan balik (feedback) yang diberikan oleh massyarakat terkait dengan pelaksanaan sosiasliasi pemilu oleh KPU Kota Pariaman. Tujuannya untuk menangkap aspirasi masyarakat terhadap pelaksanaan pemilu, sehingga mampu mengedukasi masyarakat untuk menggunakan hak pilinnya di TPS secara berkesinambungan jika pemilu dilaksanakan di Kota Pariaman.

Dengan membangun komunikasi dua arah diharapkan akan meningkatkan pengetahuan masyarakat akan pentingnya pemilu untuk kelangsungan kehidupan berbangsa dan bernegara.

\section{HASIL DAN TEMUAN}

$\mathrm{D}$ alam pelaksanaan pemilu dibutuh suatu pola komunikasi yang menjain adanya interaksi langsung langsung antara masyarakat dengan KPU Kota Pariaman. Sehingga mereka dapat secara bebas menyatakan perasaan dan pendepat mereka terhadap proses pelaksanaan pemilu yang seringkali tidak sesuai dengan apa yang mereka harapkan.

Pada saat pemilu para calon yang maju sebagai kepala daerah turun ke masyarakat hanya ketika pemilu dilaksanakan saja. Tujuannya tak lain hanya untuk mendulang suara agar menang dalam pemilu. Namun setelah terpilih sebagai kepala daerah, mereka sering lupa akan janji yang sudah diucapkan.

Kondisi seperti ini menimbulkan sikap apatis pada masyarakat untuk memilih kepala daerah. Karena masyarakat merasa mereka adalah komoditi politik yang perlu didekati apabila pemilu tiba untuk diambil simpatinya. Agar terpilih dan memenangkan pertarungan sebagai kepala daerah dalam pemilu.

Sebagaimana yang diungkapkan oleh Aldi Masyarakat Pariaman Timur yaitu; 'Kebiasaan pasangan calon yang terpilih sebagai kepala daerah ketika sudah menjabat lupa dengan janji-janji yang disampaikan saat kampanye sebagai pasangan calon, hal ini menjadi penyebab enggannya masyarakat untuk memberikan suaranya saat pelaksanaan pemilu, sebagaimana ungkapan "Bak kato urang awak, kato biaso duto, janji biaso mungkia'.

Sebagaimana diungkapkan Susi, masyarakat Pariaman Selatan, keseringannya calon kepala daerah akan sering turun dan berbaur dengan masyarakat apabila musim pemilu telah tiba. Mereka akan mengadakan berbagai macam kegaiatan sosial yang bersentuhan langsung dengan masyarakat. Dan menjadi donator utama untuk kegiatan-kegiatan kemasyarakatan. Namun akan lain ceritanya apabila mereka telah terpilih menjadi kepala daerah. Mereka akan jarang 
berbaur dengan masyarakat dan bahkan ada kesan mereka menghindar dari kegiatan kemasyarakatan. 'Kalau ka mancalon biasnyo para calon ko tibo ka kampuang manyapo masyarakat, namun setelah duduak jadi pajabat lah lupo sajo jo masyarakat'. Ungkapan seperti ini mencerminkan kekecewaan masarakat terhadap calon yng terpilih menjadi kepala daerah yang hanya turun ke masyarakat jika ada maunya saja. setelah menduduki jabatan yang diincarnya sering lupa dengan masyarakat yang telah memilih dan menjadikannya kepala daerah.

Realitas diatas merupakan suatu fenomena yang tidak terbantahkan, karena adanya kecenderungan pasangan calon lupa akan janji politik yang disampaikan ketika belum menjabat sebagai kepala daerah membuat masyarakat apatis bahwa pemilu dapat menghasilkan pemimpin atau kepala daerah yang akan mampu perobahan kearah yang lebih baik.

Fenomena ini menjadi tugas berat bagi KPU Kota Pariaman karena masyarakat suda memiliki pengalaman buruk dan terdoktrin bahwa siapa saja yang akan terpilih menjadi kepala daearah tidak akan memberikan perobahan apa-apa terhadap kepentingan rakyat. Karena masyarakat melihat ketika seorang celon telah memegang tampuk kekuasaan, maka ada kecenderungan hal utama yang mereka lakukan adalah bagi-bagi kekuasaan terutama dengan tim sukses yang telah mengantarkan mereka untuk sampai pada posisi kepala daerah. Sementara realisasi janji-janji politik yang disampaikan kepada masyarakat luas cenderung terabaikan bahkan sering tidak terealisasi sama sekali.

Merosotnya kepercayaan masyarakat terhadap pemimpin yang terpilih melalui mekanisame Pemilihan Umum (Pemilu) merupakan preseden buruk bagi perkembangan demokrasi. Karena politik selalu dikalkulasikan sebagai suatu hal yang bersifat untung rugi. Artinya masyarakat tidak lagi melihat bahwa pasangan calon yang maju sebagai celon kepala daerah yang akan mampu mengemban aspirasi dan memberikan perbaikan kehidupan melalui kebijakan yang akan mereka hasilkan saat terpilih menjadi kepala daerah nantinya. Melainkan hanya akan menguntu ngkan bagi segelintir orang saja, misalnya tim sukses atau pendukung salah satu pasangan calon yang bertarung dalam pemilihan kepala daerah.

\section{PEMBAHASAN}

$\mathrm{K}$ omunikasi pemilu dengan mengedepankan pendekatan budaya ditempuh sebagai suatu upaya untuk mengedukasi masyarakat Kota Pariaman agar memiliki kesadaran politik bahwa kepentingan seorang warga Negara yang sudah memenuhi syarat berdasarkan Undang-undang memiliki kewajiban untuk menunaikan kewajibannya dalam pemilu untuk menggunakan hak konstitusinya memilih pemimpin yang dirasa mampu mewakili aspirasi politiknya.

Salah satu pola komunikasi yang digunakan untuk menyampaikan informasi terkait dengan palaksanaan pemilu dilakukan dengan pendekatan budaya yang dikenal dengan khusus di daerah pariamah dikenal dengan ciloteh lapau. Ciloteh lapau/ ngobrol (maota) adalah perbincangan santai. Sedangkan lapau adalah kedai kopi rakyat yang biasanya dikunjungi oleh para lelaki minangkabau yang bertemu untuk memperbincangkan berbagai hal sambil menikmati minuman hangat, maota biasanya berlangsung berjam-jam tanpa henti (Nursyirwan, 2014:78).

Adapun pola komunikasi yang dibangun melalui pendekatan budaya dalam mensosialisasikan pemilihan Gubernur dan Wakil Gubernur Provinsi Sumbar pada masyarakat Kota Pariaman ditempuh dengan berbagai cara yang dirasa mampu menjangkau masyarakat. Salah satu upaya membanggun kesadaran akan pentingnya pemilu adalah dengan melakukan pendekatan kepada masyarakat dengan memanfaatkan lapau sebagai medium untuk mengedukasi masyarakat dengan upaya menekankan kepada masyarakat jika tidak ikut pemilu sama dengan melakukan tindakan pengkhianatan terhadap bangsa

186 | P a g e

DOI: 10.25077/jantro.v20.n2.p179-189.2018

JANTRO ISSN: 2355-5963 (Online)

under Lisensi Creative Commons Atribusi-BerbagiSerupa 4.0 Internasional 
dan Negara karena membiarkan pemerintahan yang terbentuk tidak berdsaarkan pilihan masyrakat banyak.

Sebagai orang Minangkabau, lapau merupakan ruang sosial khusus laki-laki. Secara empiric, lapau merupakan kedai kopi yang biasa terdapat dikampungkampung dan di beberapa sudut kota. Kedai kopi biasanya dikunjungi kaum lelaki untuk berbincang-bincang (ngobrol). Sedangkan secara emik. Lapau dipahami orang Minangkabau sebagai konstruksi dan onteraksi sosial khusus laki-laki (Nursyrwan, 1993:77).

Terkait dengan pelaksanaan sosialisasi pemilu, selain mengandalkan metode langsung dengan pendekatan budaya melalui 'Ciloteh Lapau' maka perlu dipersiapkan media yang dapat digunakan untuk kegiatan sosialisasi pemilu yaitu;

1. Media cetak (Koran, Leaflet, Pamflet dan Baliho

2. Media Elektronik (iklan layanan masyarakat di Radio yang berisi himbauan dan untuk menggunakan hak Pilih

3. Media online (melalui FB, Twitter dan IG KPU Kota Pariaman).

Pemilihan media tersebut dilihat dari jumlah pengguna yang ada di Kota Pariaman. Sehingga media yang digunakan sebagai sarana penyampaian pesan dapat efektif menjangkau masyarakat Pariaman. Pemanfaatan media sebagai sarana sosialisasi adalah sebagai medium yang digunakan untuk menyampaikan pesan kepada masyarakat. Sehingga tidak ada lagi masyarakat Kota Pariaman yang tidak mengetahui kapan hari, waktu dan tanggal pemungutan suara. Serta siapa saja calon kepala daerah yang maju sebagai Calon Gubernur dan Wakil Gubernur Provinsi Sumatera Barat. Pada Pilgub tahun 2015 terdapat dua pasangan calon yaitu;

1. Dr. H. Irwan Prayitno, M,Sc dan H. Nasrul Abit

2. H. Muslim Kasim dan Fauzi Bahar

Berdasarkan hasil rekapitulasi suara oleh KPU Kota Pariaman, pasangan IP-NA memperoleh suara sebesar 16.185 suara sedangkan MK-FB memperoleh suara sebesar 14.887 suara.
Jika dilihat dari faktor kedaerahan, pasangan MK-FB seharusnya memperoleh kemenangan di Kota Pariaman. Karena berdasarkan kedaerahan Kota Pariaman adalah kampung halaman dari Muslim Kasim. Namun pada kenyataannya hal itu tidak terjadi.

Pasangan MK-FB tidak memperoleh suara yang lebih signifikan dibandngkan dengan IP-NA. Artinya masyarakat Kota Pariaman adalah pemilih rasional dalam memilih pasangan calon akan dipilih menjadi kepala daerah. Sebagaimana hasil wawancara dengan Pemuka Masyarakat Indra jaya menyatakan bahwa ada beberapa hal yang mendasari masyarakat Kota pariaman tidak memilih putra daerah sebagai kepala daerah. Pertama, adanya luka sejarah yang masih membekas di ingatan masyarakat terkait dengan penolakan pemekaran wilyah Kota Pariaman menjadi Kota Pariaman. Kedua, tidak ada gebrakan pembangunan yang berarti saat menjadi kepala daerah. Ketiga, karakter yang kurang disukai masyarakat.

Artinya, keterkaitan antara kepercayaan masyarakat terhadap pasangan calon yang maju sebagai kepala daerah tidak dipengaruhi oleh faktor kedaerahan, karena masyarakat sudah rasional menentukan siapa yang dirasa mampu untuk mewakili aspirasinya.

Pentingnya membangun suatu pola komunikasi yang berbasis pendekatan budaya dalam rangka meningkatkan kesadaran masyarakat dalam menggunakan hak pilih dalam pelaksanaan pemilu perlu dilakukan secara langsung. Dengan menempatkan masarakat sebagai lawan bicara (audience) dengan mengedepankan metode informal. Dimana diskusi dirancang dilapau (warung) tempat berkumpul untuk membicarakan banyak hal yang sedang Happening di masyarakat adalah suatu solusi yang dilakukan oleh KPU Kota Pariaman sebagai upaya untuk membangun pola komunikasi yang lebih menekankan pada interaksi langsung dengan masyarakat, sehinga KPU mampu menangkap ide dan permasalahan yang mereka hadapi ketika hendak menggunakan hak pilinnya dalam pemilihan kepala daerah 
ataupun pemilu yang akan dilaksanakan nantinya oleh KPU Kota Pariaman.

\section{E. KESIMPULAN}

$\mathrm{P}$ ola komunikasi dibutuhkan agar informasi yang harusnya disampaikan kepada publik dapat terselurkan dengan baik. Apakah dengan menggunakan media atau secara langsung adalah cara yang ditempuh agar maksud yang ingin dituju dapat tersampaikan dengan baik.

Dalam melaksanakan sosialisasi Pemilu sebagai salah satu upaya yang dilakukan agar masyarakat mengetahui dan memahami akan pentingnya pelaksanaan pemilu berkaitan erat dengan kepentingan bersama (menyangkut hajat orang banyak). Maka dilakukanlah sosialisasi pemilu agar informasi kepemiluan dapat tersebar luas kepada masyarakat.

Namun pada kenyataannya, sosialisasi yang dilakukan melalui media tidak mampu menumbuhkan kesadaran masyarakat akan pentingnya menggunakan hak pilih pada saat pelaksanaan pemilu.

Untuk itu dilakukan cara-cara yang mudah diterima masyarakat salah satunya melalui pendekatan budaya, khusus untuk Kota Pariaman dimana masyarakatnya sangat gemar berkumpul dilapau, sehingga lapau menjadi suatu bagian yang tidak dapat dipisahkan dari pergaulan sosial masyarakat. Maka KPU Kota Pariaman sebagai penyelenggara pemilu ditingkat daerah, mencoba melakukan pendekatan melalui budaya maota-ota (ngobrol) dilapau yang kemudian dikemas dalam acara 'Ciloteh Lapau' dalam rangka sosialisasi pemilu kepada masyarakat luas. Dengan mengutamakan terjadinya dilogh langsung antara KPU sebagai penyelenggara pemilu dengan seluruh masyarakat yang ada saat itu. Adapun pola komunikasi yang dibangun berdasarkan pendekatan budaya ini menitik beratkan pada dialogh, dimana tidak hanya KPU yang bisa sebagai sumber informasi (pemateri), melainkan masyarakat yang ada juga dapat berperan sebagai pembicara. Sehingga metode interaktif secara langsung ini diharapkan akan mampu menarik animo dan menimbulkan kesadaran mayarakat akan pentinya untuk menggunakan hak pilih di TPS.

Berkaca dari jumlah partisipasi yang diperoleh dari pelaksanakaan pemilihan Gubernur dan Wakil Gubernur tahun 2010 lalu, dimana pola komunikasi yang dibangun haya bersifat satu arah saja, dan hanya mengandalkan alat peraga barupa media luar ruang (baliho dan spanduk). Maka pada Pilgub Sumbar tahun 2015 KPU Kota Pariaman berhasil memperbaiki jumlah partisipasi sebesar 1,50\%. Hal ini juga sekaligus memperbaiki ranking Kota Pariaman yang ditahun 2010 berada pada rangking 18 dari Sembilan belas kabupatan dan Kota yang ada di Sumatera Barat. Namun pada tahun 2015 berhasil diperbaiki menjadi rangking 7 (Tujuh) ditingkat Sumatera barat.

Artinya, sosialisasi pemilu sebaiknya diarahkan pada pendekatan budaya sebagai suatu pola yang dapat digunakan untuk mengedukasi masyarakat akan pentingnya pelaksanaan pemilu bagi kelangsungan pemerintahan yang akan datang. Sehingga tingkat partisipasi masyarakat dalam pemilu dapat ditingkatkan.

Penggunaan lapau sebagai media untuk meningkatkan literasi masyarakat akan pentingnya pemilu dalam tatanan kehidupan yang lebih besar dapat dilakukan dengan cara-cara yang lebih bisa diterima, karena mengedepankan kebiasaan-kebiasaan yang telah lekat di masyarakat.

Lapau merupakan institusi yang telah lama akrab dengan masyarakat. Hingga saat ini, lapau merupakan media yang tidak tergerus oleh perkembangan aman ataupun media mainstream yang menerpa masyarakat kita.

Dalam tatanan budaya minang kabau, lapau atau kedai kopi tradisional adalah tempat berlangsungnya diskusi banyak hal, selain itu bisa saja sebagai tempat untuk mengkritik serta menyampaikan gagasan tertentu (Darwis.2013:24).

Karena lapau dapat didatangi oleh siapa saja, dan sejatinya menjadi wadah dan tempat berkumpulnya masyarakat dari $188 \mid$ P a g e

DOI: 10.25077/jantro.v20.n2.p179-189.2018 
berbagai kalangan di Kota Pariaman. Maka saat pemilu tiba, lapau menjadi bagian penting yang dapat dijadikan sebagai tempat untuk menyampaikan program kerja, visi dan misi masing-masing pasangan calon.

Melihat fenomena tersebut, KPU Kota Pariaman berupaya untuk terjun langsung kemasyarakat dengan memafaatkan media lapau ini dengan tujuan untuk memberikan pendidikan kepemiluan kepada masyarakat dengan menitik beratkan pada kewajiban warga Negara untuk melaksanakan perannya dalam rangka menjaga stablitas sosial dan pemerintahan yang berkorelasi langsung dengan kepentingan serta hajat hidup orang banyak. Maka dilakukanlah sosialsiasi pemilu dengan metode 'Ciloteh Lapau' sebagai media komunikasi yang digunakan KPU Kota Pariaman dalam rangka melakukan pendidikan pemilu secara peruasif, edukatif dan informatif dengan memperhatikan tatanan sosial dan budaya yang ada di masyarakat Kota Pariaman dalam upaya untuk meningkatkan kesadaran masyarakat (awareness) dalam menggunakan hak pilihnya dalam Pemilu.

\section{DAFTAR PUSTAKA}

Asshiddiqie, Jimly (2006). Pengantar Ilmu Hukum Tata Negara, Jakarta: Sekertariat Jendral dan Kepanitraan Mahkamah Konstitusi

Damsar. (2010). Pengantar Sosiologi Politik. Jakarta: Kencana Preneda Group

Darwis, Yuliandre, (2013). Sejarah perkembangan Pers Mianangkabau (1959-1945). Jakarta: PT. Gramedia Pustaka Utama

Devito, A. Joseph. (1997). Komunikasi Antar Manusia, Terjemahan Agus Maulana. Jakarta: Professional Books

Effendy, Nursyirwan, (2014). Budaya Politik Khas Minangkabau, Masyarakat Indonesia, Vol 40 (1) Juni 2014

Kriyantono, Rakhmat. (2014). Teori Publik Relation Perspektif Barat dan Lokal. Jakarta: PT. Kencana Prenadamedia Group

Koentjaraningrat (1981), Kebudayaan Mentalitas dan Pembangunan, Bandung: Srikandi Media.

Laporan Rekapitulasi Penghitungan Suuara Pemilihan Gubernur dan Wakil Gubernur Provinsi Sumatera Barat di Tingkat Kota Pariaman tahun 2015

Liliweri, Alo. (2011). Dasar-Dasar Komunikasi Antar Budaya. Surabaya: Pustaka Pelajar

Moleong, J, Lexy. (2013). Metode Penelitian Kualitatif Edisi Refisi, Bandung: Remaja Rosdakarya

Mulyana, Deddy dan Rakhmat, Jalaluddin. (2005). Komunikasi Antar Budaya, Bandung: Remaja Rosdakarya

Mulyana, Deddy, (2004). Metode Penelitian Kualitatif Paradigma Baru IImu Komunikasidan IImu Sosial Lainnya, Bandung: Remaja Rosdakarya

Nurhakki. (2013). Budaya Komunikasi Dalam meningkatkan Partisipasi Politik Prempuan, Stain Parepare

Rasul M, Najmuddin dkk, (2015). Penggunaan Media, Norma Kewarganegaraan dan Partisipasi Politik Dalam Era Transisi ke Demokrasi di Indonesia. Malaysian Jurnal Of Communication Jilid 31 (1) 2015: 187-204

Rivers, William L. dan Jay W. Jensen (2004), Media Massa dan Masyarakat Modern, Jakarta: Prenada Media

Sugiyono, (2016). Metode Penelitian Kualitatif dan Kuantitatif dan R\&D, Bandung; Alfabeta.

Yose Hendra, (2017). Demokrasi Lapau diakses tanggal 18/8/2017 